\title{
Seeds Germination and Seedlings Analysis of Saussurea Costus Royle Ex Benth. In High and Low Altitudinal Villages of District Uttarkashi (Uttarakhand)
}

\author{
M.P.S. Parmar ${ }^{1}$, Lokendra Singh Negi ${ }^{2}$ and Shanti Ramola ${ }^{3}$ \\ ${ }^{I}$ Department of Botany R. C. U. Govt. P. G. College, Uttarkashi- 249193 (Uttarakhand) \\ ${ }^{2,3}$ Sankalp Samajik Sanstha Genwala Barsali Uttarkashi
}

\begin{abstract}
SUMMARY
Saussurea costus (Falc.) Lipschitz, syn. Saussurea lappa C. B. Clarke is a well known and important medicinal plant widely used in several indigenous systems of medicine for the treatment of various ailments, viz. asthma, inflammatory diseases, ulcer and stomach problems. Different pharmacological experiments in a number of in- vitro and in- vivo models have convincingly demonstrated the ability of Saussurea costus to exhibit anti-inflammatory, anti-ulcer, anti-cancer and hepatoprotective activities, lending support to the rationale behind several of its traditional uses. The present review is an up-to-date and comprehensive analysis of seed germination, survival percentage and seeding analysis of Saussurea costus in lower and higher Himalayan altitudinal villages of district Uttarkashi.

The present study deals with successful seeds germination, survival percentage and seedlings analysis of this species using both field and within the polyhouse techniques in low and high altitudinal villages. The materials were collected from the Besaj Sang Ikai, Uttarkashi. Vegetative propagation was achieved by rooting runner cuttings. Seedlings were measured by seed germination and survival percentage, root and shoot length. A significant increment in root length was recorded in high altitudinal Polyhouse condition as compared to low altitude. In low altitudinal village Genwala, open field condition seed germination percentage and survival percentage ranged from $5.00 \%-18.18 \%$ and $18.18 \%$ to $25.00 \%$ while in low altitudinal village seed germination percentage and survival percentage within Polyhouse were ranged from $23.00 \%$ to $45.00 \%$ and $40.45 \%$ to $66.70 \%$ respectively. Highest percentage of seed germination and survival percentage were noticed in high altitudinal village, Bagori (Within Polyhouse) from $40.50 \%$ to $60.00 \%$ (seed germination), $60.70 \%$ to $76.50 \%$ (survival percentage) respectively. The leaves are produced in a dense basal rosette, and spiral up the flowering stem. The woolly hairs in high altitude species of the family are the densest, and aid in thermoregulation of the flowers, minimizing frost damage at night, and also preventing ultraviolet light damage from the intense high altitude sunlight.
\end{abstract}

Keywords:- Conventional, hepatoprotective activities, Polyhouse, multiplication, thermoregulation etc.

\section{INTRODUCTION}

Sassurea costus (Falc.) Lipsch. locally known as Kuth, belong to family Asteraceae is a perennial aromatic herb. It is 1-2 m tall, with a thick fibrous stem. Leaves radical with long lobately winged stalks. Root stout, carrot like, $60 \mathrm{~cm}$ long, possessing a characteristic penetrating odour. Flowers are dark purple or black in colour. Nayar and Shastry, 1988; Stainton, 1988 and Samant et al., 1998 reported that it is distributed between 2500- 3000 masl in the Himalaya, and native to the Himalayan region. Its natural populations are reported from the higher elevations of Jammu and Kashmir and Himachal Pradesh (Aswal and Mehrotra, 1994) and now cultivated in Kashmir, Himachal Pradesh and in some part of Uttarakhand. The medicinal properties of Saussurea costus are well documented in different systems of medicine. Its roots have a strong and sweet aromatic odour with bitter tastes, and used as antiseptic, in controlling bronchial asthma (Anonymous, 1972). It is also used for curing various diseases like dysentery, rheumatism, cholera, jaundice, cold, fever and stomachache etc.

The oil is pale yellow to brownish in color and used in high grade perfumes and in the preparation of hair oil. Because of an endemic species to the Himalaya, the distribution of this species is quite restricted to extremely narrow geographical range (Siddique et al., 2001) which makes it more susceptible to extinction. Being an endangered species (Anonymous, 1972, Nayar and Shastry, 1987, 1988, 1990), enlisted in Appendix I of CITES (Convention of International Trade in Endangered Species of Wild). Its trade is strictly prohibited under Foreign trade Development Act-1992. Paclobutrazol is a strong growth retardant used in many plants to control their growth and development (Hamid and Williams 1997, Gonzalez et al., 1999). 
Ethepon, an ethylene releasing compound has also demonstrated a capacity to modify plant growth (Muse and Holcomb 1997, Banon et al., 1998, Cardoso et al., 1998).

\section{MATERIALS AND METHODS}

While exploring the seed germination and survival percentage diversity in high and low altitudinal conditions we recorded observations on distribution, altitudinal range, habit and habitat of the Saussurea species. Knowledge of indigenous uses was gathered through interviews with local inhabitants. Seeds of Saussurea costus were sown in within Polyhouse and open field condition and in Iron trays in soil compositions of soil: sand: litter in (1:1:1, v. v. v) proportion during the month of October 2010 inside polyhouse at High Altitude Plant Physiology Research Centre (2900 masl, Bagori) and Ganwala (1260 masl) Uttarkashi, Uttarakhand. Five plants for each low, high and Polyhouse conditions were dug out for observing the growth parameters such as leaf area $(\mathrm{cm} 2)$, root length $(\mathrm{cm})$ and dry weight $(\mathrm{mg})$ of economically important part i.e. root/rhizome. These plants were taken to laboratory, washed with running water. Further, all samples were dried at $80^{\circ} \mathrm{C}$ for 24 hours or until constant weight to measure dry weight in milligram per plant. Seed germination and survival percentage were calculated in $15^{\text {th }}$ days interval. Following parameters were studied during the research work:

1. Seed germination and survival percentage

2. Seedlings growth parameters

3. Root and shoot length

\section{RESULT AND DISCUSSION}

In the present study all the species were herbaceous in nature and distributed between 1260 masl to 3000 masl. This high species diversity may be due to varied soil, climate and geography of the zone, which gives rise to many micro and macro habitats. The high altitudinal region (within polyhouse) of the Himalayas, particularly Bagori, contains the highest percentage of seed germination and survival percentage while in low altitudinal village (Genwala) low germination and survival percentage were noticed. In low altitudinal village Genwala, open field condition seed germination percentage and survival percentage ranged from 5.00\% $18.18 \%$ and $18.18 \%$ to $25.00 \%$ while in low altitudinal village seed germination percentage and survival percentage within Polyhouse were ranged from $23.00 \%$ to $45.00 \%$ and $40.45 \%$ to $66.70 \%$ respectively.

In open field (Bagori, high altitudinal village) condition seed germination and survival percentage were ranged from $29.00 \%$ to $75.50 \%$ and $55.50 \%$ to $71.90 \%$ while within Polyhouse seed germination and survival percentage were ranged from $40.50 \%$ to $60.00 \%$ and $60.70 \%$ to $76.50 \%$ respectively. Highest percentage of seed germination and survival percentage were noticed in high altitudinal village, Bagori (Within Polyhouse) as compared to low altitudinal village. Mean root and shoot length in Genwala (open field condition) were ranged from 0.598 to 1.002 and 0.454 to 1.023 while within Polyhouse it was ranged from 1.134 to 1.748 and 0.522 to 1.328 respectively. In Bagori (open field condition) mean root and shoot length were ranged from 1.115 to 1.748 and 0.722 to 1.328 while in within Polyhouse mean root and shoot length were ranged from 1.762 to 3.291 and 1.564 to 3.100 respectively.

\section{CONCLUSIONS}

The present study provides comprehensive information on the diversity, distribution, habitat preference, nativity, endemism and status of Saussurea in low and high himalayan regions. A few of the species are known for their economic value and, therefore, other species should also be investigated for their economic importance. S. affinis, S. auriculata, S. bracteata, S. costus, S. gossypiphora and S. obvallata were recorded as multipurpose species, used as medicine, food, fodder, fuel, and for ornamental and religious purposes. Considering the high industrial demand for raw material and the endangered status of $S$. costus, S. gossypiphora, S. obvallata and $S$. simpsoniana, these 4 species should be priorities for conservation (in situ and ex situ) throughout the himalayan regions. Population assessment of the native, endemic and rare/endangered species using standard ecological methods has been suggested for the quantification of the existing stock of these species in their natural habitats. A review of the literature indicates that propagation and cultivation techniques are available only for a few species of Saussurea and, therefore, these techniques need to be developed, particularly for rare/ endangered and multipurpose species. Native communities need to be made aware of the sustainable use and conservation value of the species of Saussurea. 
Seeds Germination and Seedlings Analysis of Saussurea Costus Royle Ex Benth...

Table 1.1: Temporal seed germination percentage and survival percentage (low and high altitudinal villages) of SAUSSUREA COSTUS (Open field condition and within Polyhouse).

\begin{tabular}{|c|c|c|c|c|c|c|c|c|c|c|c|c|}
\hline \multirow[t]{2}{*}{ Sites Name } & \multicolumn{6}{|c|}{ Germination Percentage } & \multicolumn{6}{|c|}{ Survival percentage } \\
\hline & R1 & $\mathbf{R 2}$ & $\mathbf{R 3}$ & R4 & R5 & R6 & R1 & $\mathbf{R 2}$ & $\mathbf{R 3}$ & $\mathbf{R 4}$ & R5 & R6 \\
\hline $\begin{array}{lr}\text { Low } & \text { altitudinal } \\
\text { Village } & \text { Genwala } \\
\text { (Open } & \text { field } \\
\text { condition) } & \end{array}$ & $\begin{array}{l}11.0 \\
0\end{array}$ & 5.00 & $\begin{array}{l}17.0 \\
0\end{array}$ & $\begin{array}{l}14.0 \\
0\end{array}$ & $\begin{array}{l}18.0 \\
0\end{array}$ & $\begin{array}{l}17.0 \\
0\end{array}$ & $\begin{array}{l}18.1 \\
8\end{array}$ & $\begin{array}{l}21.0 \\
0\end{array}$ & $\begin{array}{l}23.0 \\
0\end{array}$ & $\begin{array}{l}25.0 \\
0\end{array}$ & $\begin{array}{l}22.0 \\
0\end{array}$ & $\begin{array}{l}19.0 \\
0\end{array}$ \\
\hline & $\mathbf{R} 1$ & $\mathbf{R 2}$ & $\mathbf{R 3}$ & R4 & $\mathbf{R 5}$ & R6 & R1 & $\mathbf{R 2}$ & $\mathbf{R 3}$ & $\mathbf{R 4}$ & $\mathbf{R 5}$ & R6 \\
\hline $\begin{array}{l}\text { Low altitudinal } \\
\text { Village , Genwala } \\
\text { (within Polyhouse) }\end{array}$ & 23.00 & 23.00 & $\begin{array}{l}27.0 \\
0\end{array}$ & $\begin{array}{l}35.0 \\
0\end{array}$ & $\begin{array}{l}23.0 \\
0\end{array}$ & $\begin{array}{l}45.0 \\
0\end{array}$ & $\begin{array}{l}47.8 \\
2\end{array}$ & $\begin{array}{l}60.5 \\
0\end{array}$ & $\begin{array}{l}55.8 \\
0\end{array}$ & $\begin{array}{l}40.4 \\
5\end{array}$ & $\begin{array}{l}66.7 \\
0\end{array}$ & $\begin{array}{l}60.0 \\
0\end{array}$ \\
\hline & $\mathbf{R} 1$ & $\mathbf{R 2}$ & R3 & R4 & R5 & R6 & R1 & $\mathbf{R 2}$ & R3 & R4 & R5 & R6 \\
\hline $\begin{array}{lr}\text { High } & \text { altitudinal } \\
\text { Village }, & \text { Bagori } \\
\text { (Open } & \text { field } \\
\text { condition } & \end{array}$ & 54.60 & 40.50 & $\begin{array}{l}60.4 \\
0\end{array}$ & $\begin{array}{l}59.0 \\
0\end{array}$ & $\begin{array}{l}48.6 \\
0\end{array}$ & $\begin{array}{l}60.0 \\
0\end{array}$ & $\begin{array}{l}57.3 \\
7\end{array}$ & $\begin{array}{l}71.9 \\
0\end{array}$ & $\begin{array}{l}56.4 \\
0\end{array}$ & $\begin{array}{l}55.5 \\
0\end{array}$ & $\begin{array}{l}65.6 \\
0\end{array}$ & $\begin{array}{l}70.0 \\
0\end{array}$ \\
\hline & $\mathbf{R 1}$ & $\mathbf{R 2}$ & $\mathbf{R 3}$ & R4 & $\mathbf{R 5}$ & R6 & $\mathbf{R 1}$ & $\mathbf{R 2}$ & $\mathbf{R 3}$ & $\mathbf{R 4}$ & $\mathbf{R 5}$ & R6 \\
\hline $\begin{array}{l}\text { High altitudinal } \\
\text { Village , Bagori } \\
\text { (Within } \\
\text { Polyhouse) }\end{array}$ & 43.00 & 29.00 & $\begin{array}{l}46.9 \\
0\end{array}$ & $\begin{array}{l}65.0 \\
0\end{array}$ & $\begin{array}{l}75.5 \\
0\end{array}$ & $\begin{array}{l}60.4 \\
0\end{array}$ & $\begin{array}{l}70.0 \\
0\end{array}$ & $\begin{array}{l}75.5 \\
0\end{array}$ & $\begin{array}{l}60.7 \\
0\end{array}$ & $\begin{array}{l}60.7 \\
0\end{array}$ & $\begin{array}{l}65.4 \\
0\end{array}$ & $\begin{array}{l}76.5 \\
0\end{array}$ \\
\hline
\end{tabular}

Table: 1.2. Data table showing mean length of root and shoot in $15^{\text {th }}$ days old seedlings of SAUSSUREA COSTUS (Open field condition and within Polyhouse).

\begin{tabular}{|c|c|c|c|c|c|c|c|c|c|c|c|c|}
\hline \multirow[t]{2}{*}{ Sites Name } & \multicolumn{6}{|c|}{ Mean length of Root } & \multicolumn{6}{|c|}{ Mean Length of Shoot } \\
\hline & R1 & $\mathbf{R 2}$ & $\mathbf{R 3}$ & R4 & R5 & R6 & R1 & $\mathbf{R 2}$ & R3 & R4 & R5 & R6 \\
\hline $\begin{array}{lr}\text { Low } & \text { altitudinal } \\
\text { Village } & \text { Genwala } \\
\text { (Open } & \text { field } \\
\text { condition) } & \\
\end{array}$ & $\begin{array}{l}0.59 \\
8\end{array}$ & 0.737 & $\begin{array}{l}0.69 \\
5\end{array}$ & $\begin{array}{l}1.00 \\
2\end{array}$ & $\begin{array}{l}0.66 \\
8\end{array}$ & $\begin{array}{l}0.73 \\
1\end{array}$ & $\begin{array}{l}0.89 \\
6\end{array}$ & $\begin{array}{l}0.45 \\
4\end{array}$ & $\begin{array}{l}0.94 \\
1\end{array}$ & $\begin{array}{l}0.87 \\
1\end{array}$ & $\begin{array}{l}0.91 \\
1\end{array}$ & $\begin{array}{l}1.02 \\
3\end{array}$ \\
\hline & R1 & $\mathbf{R 2}$ & $\mathbf{R 3}$ & R4 & $\mathbf{R 5}$ & R6 & R1 & $\mathbf{R 2}$ & $\mathbf{R 3}$ & $\mathbf{R 4}$ & $\mathbf{R 5}$ & R6 \\
\hline $\begin{array}{l}\text { Low altitudinal } \\
\text { Village , Genwala } \\
\text { (within Polyhouse) }\end{array}$ & 1.293 & 1.748 & $\begin{array}{l}1.26 \\
9\end{array}$ & $\begin{array}{l}1.13 \\
4\end{array}$ & $\begin{array}{l}1.11 \\
5\end{array}$ & $\begin{array}{l}1.15 \\
3\end{array}$ & $\begin{array}{l}1.32 \\
8\end{array}$ & $\begin{array}{l}1.21 \\
0\end{array}$ & $\begin{array}{l}1.04 \\
7\end{array}$ & $\begin{array}{l}0.72 \\
2\end{array}$ & $\begin{array}{l}1.03 \\
6\end{array}$ & $\begin{array}{l}1.23 \\
4\end{array}$ \\
\hline & R1 & $\mathbf{R 2}$ & $\mathbf{R 3}$ & $\mathbf{R 4}$ & R5 & R6 & $\mathbf{R} 1$ & R2 & $\mathbf{R 3}$ & R4 & $\mathbf{R 5}$ & R6 \\
\hline $\begin{array}{lr}\text { High altitudinal } \\
\text { Village , } \\
\text { (Open } \\
\text { condition }\end{array}$ & 0.867 & 1.678 & $\begin{array}{l}1.34 \\
5\end{array}$ & $\begin{array}{l}1.90 \\
3\end{array}$ & $\begin{array}{l}2.10 \\
1\end{array}$ & $\begin{array}{l}2.11 \\
0\end{array}$ & $\begin{array}{l}0.45 \\
3\end{array}$ & $\begin{array}{l}0.98 \\
7\end{array}$ & $\begin{array}{l}0.87 \\
6\end{array}$ & $\begin{array}{l}1.76 \\
3\end{array}$ & $\begin{array}{l}1.43 \\
2\end{array}$ & $\begin{array}{l}1.02 \\
1\end{array}$ \\
\hline & R1 & $\mathbf{R 2}$ & $\mathbf{R 3}$ & R4 & $\mathbf{R 5}$ & R6 & $\mathbf{R 1}$ & $\mathbf{R 2}$ & $\mathbf{R 3}$ & R4 & R5 & R6 \\
\hline
\end{tabular}


Seeds Germination and Seedlings Analysis of Saussurea Costus Royle Ex Benth...

\begin{tabular}{|l|l|l|l|l|l|l|l|l|l|l|l|l|}
\hline $\begin{array}{l}\text { High altitudinal } \\
\text { Village , Bagori } \\
\text { (Within } \\
\text { Polyhouse) }\end{array}$ & 1.762 & 2.786 & 2.89 & 2.56 & 2.90 & 3.29 & 1.56 & 2.34 & 2.22 & 2.12 & 2.34 \\
2 & & & & & 1 & 1 & 4.10 \\
0
\end{tabular}

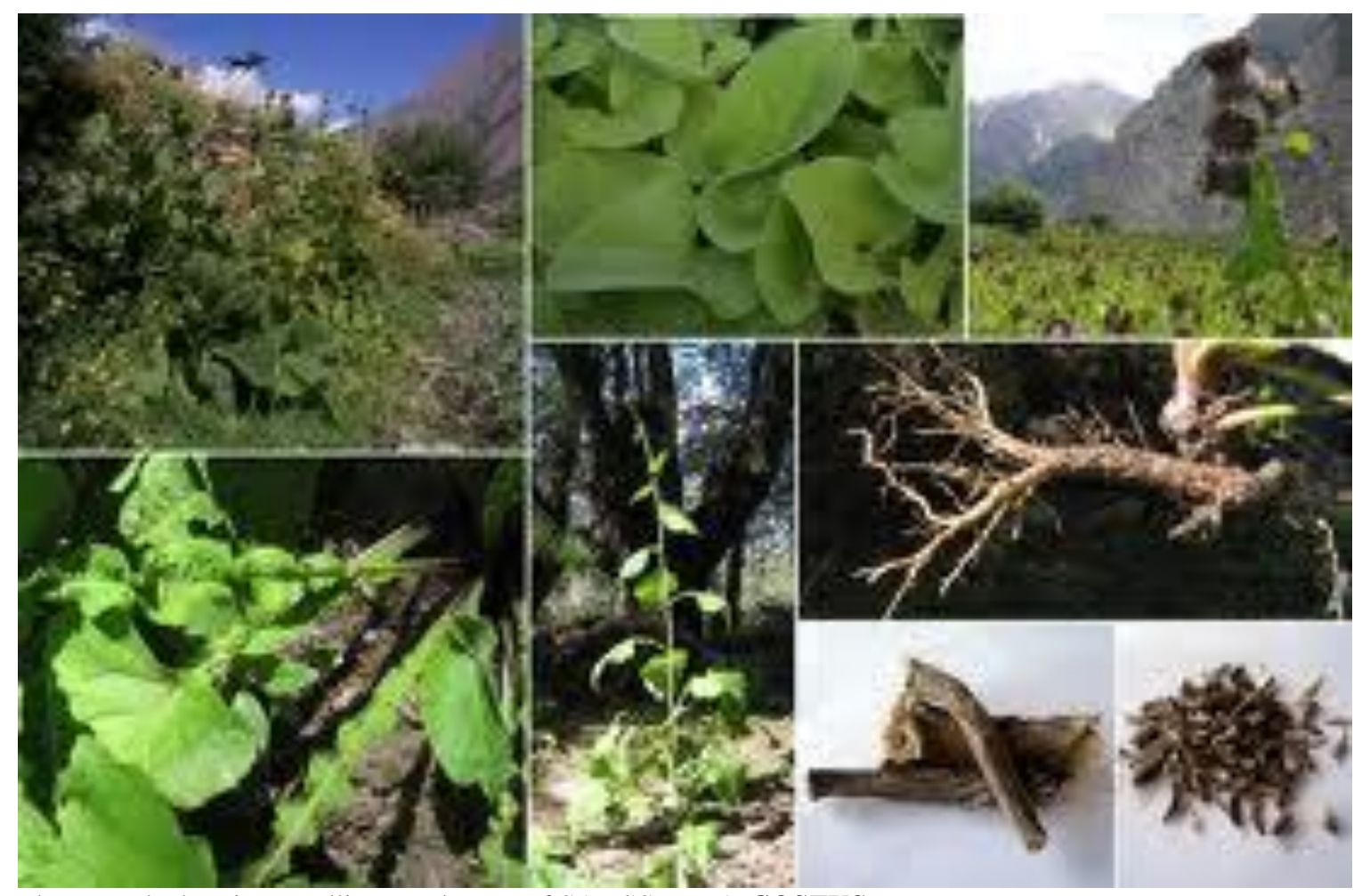

Photograph showing seedlings and roots of SAUSSUREA COSTUS

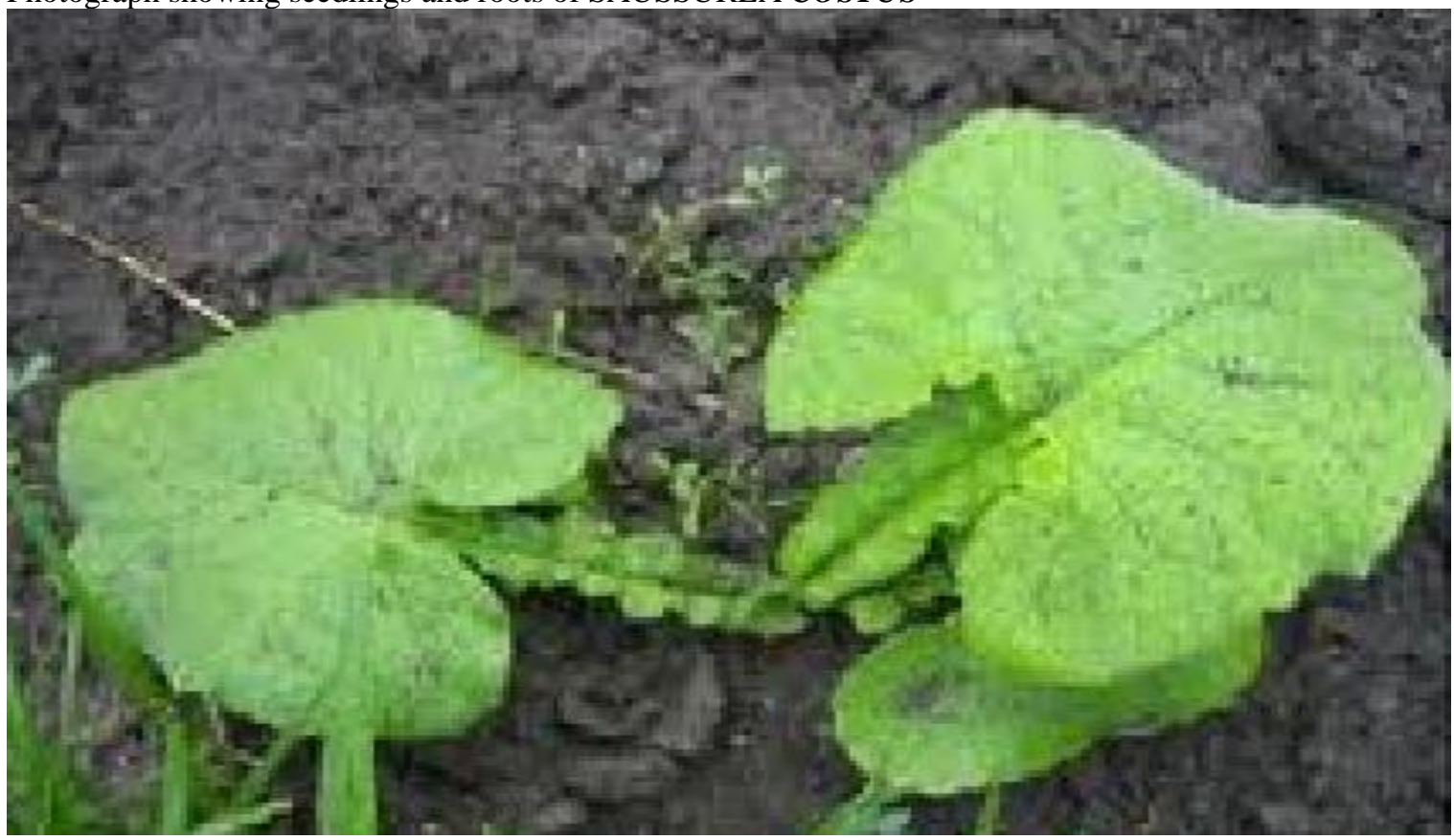

45 days young seedling of SAUSSUREA COSTUS 


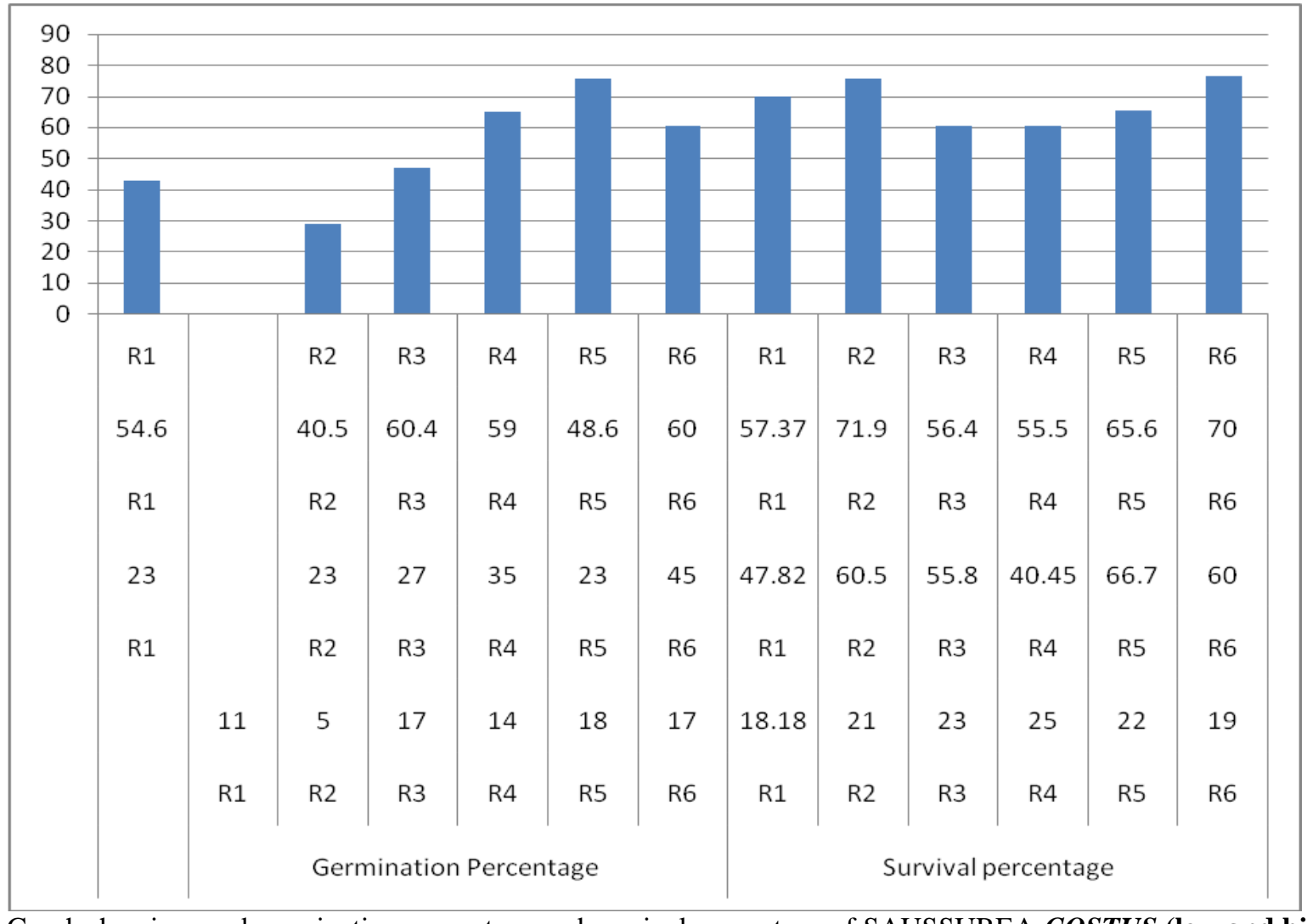

Graph showing seed germination percentage and survival percentage of SAUSSUREA COSTUS (low and high altitudinal villages).

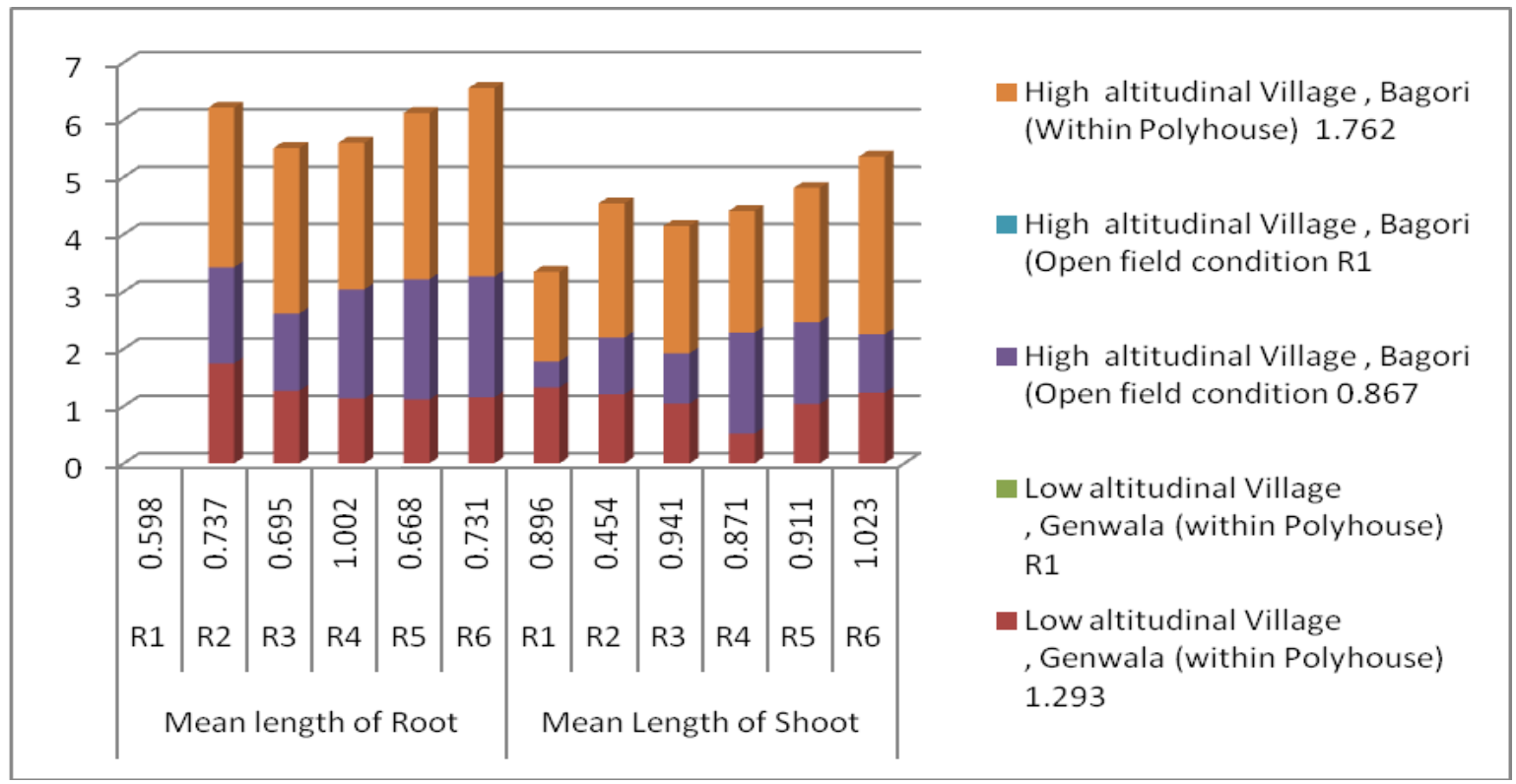

Graph showing mean length of Root and Shoot of SAUSSUREA COSTUS

\section{ACKNOWLEDGEMENTS}

The authors are thankful to the Department of Science and Technology (DST) for the financial support in the form of research project and also thanks to Tribal population of the project area and village leader Mr.Hira Lal also

\section{REFERENCES}

[1]. Nayar MP and Shastry ARK. (1987, 1988 and 1990). Red data book of Indian Plants. Vol. I, II \& III. BSI, Calcutta. 
[2]. Stainton A. (1988). Flowers of the Himalaya. A Supplement. Oxford University Press, Delhi.

[3]. Samant SS, Dhar U and Palni LMS. (1998). Medicinal Plants of Indian Himalaya: Diversity, Distribution, Potential Values. HIMAVIKAS publication. No. 13, Gyan. Prakash., Nainital.

[4]. Aswal BS and Mehrotra B.N. (1994). Flora of Lahaul-Spiti (A cold desert in North Western Himalaya). Bishen Singh Mahendra pal Singh, Dehra Dun, Uttarakhand, India.

[5]. Anonymous. The wealth of India. 1972; Vol. IX: Rh-So, CSIR, New Delhi.

[6]. Siddique MAA, Wafai BA, Riya AM and Sheikh AS. (2001). Conservation of Kuth (Saussurea costus) - a threatened medicinal plant of Kashmir Himalaya. Himalayan Medicinal Plants: potential and Prospects, pp.197-204.Ed. Samant, S.S., Dhar, U. and Palni, L.M.S., HIMAVIKAS, occasional publication no. 14, Gyan. Prakash., Nainital.

[7]. Hamid M. N. and Williams R. R. (1997). Effect of different types and concentrations of plant growth retardants on Sturtís desert pea (Swainsonia Formosa). Scientia Horticulturae 71: 79-85.

[8]. Gonzalez A, Lozano M, Casas JL, Banon S, Fernandez J.A. and Franco J. A. (1999). Influence of growth retardants on the growth and development of Zantedeschia aethiopica. Acta Horticulturae 486: 333-337.

[9]. Banon S, Gonzalez A, Fernandez J. A. and Franco J. A. (1998). The effect of ethephon on the growth and development of Liatris spicata Journal of Horticultural Science \& Biotechnology 73:777-784.

[10]. Cardoso AI, Dasilva N and Dellavecchia PT. Effect of ethephon on a summer squash line. Horticultura Brasileira. 1998; 16: 140-145. 